Bader A. Alyoubi,

Ph.D., Associate Professor, University of Jeddah, Saudi Arabia

Mohammad Ali Yousef Yamin,

Ph.D., University of Jeddah, Saudi Arabia

\title{
THE IMPACT OF TASK TECHNOLOGY FIT ON EMPLOYEE JOB PERFORMANCE
}

\begin{abstract}
In today's dynamic global business economy, the use of information technology has become an essential and pervasive technique for organizational success. In this essence, the present study extends the unified theory of acceptance and use of technology with task technology fit to see how underpinned factors impact on employee intention to adopt information technology and enhance employee job performance. In order to test the proposed research model, the respondent's observations are required. Therefore, an administrative survey was conducted towards Saudi public organizations. A survey questionnaire was distributed among middle-level managers working in HR departments of Saudi Public organizations. In response to administrative survey 398 questionnaires were returned with a response rate of $79.6 \%$. Among 398 questionnaires 38 were discarded due to inappropriate answers and 358 questionnaires were finally used for structural equation modelling. The inclusion criterion was that $H R$ managers must have knowledge about online services offering by respective organizations to employees. For data analysis, structural equation modelling approach was used. Results indicate that the extended the unified theory of acceptance and use of technology model has substantial power and explained $R^{2} 77.0 \%$ variance in employee intention to adopt the technology. The effect size analysis $\left(f^{2}\right)$ showed that within extended model effort expectancy was the most important factor. The predictive relevance $Q^{2}$ of the model was also adequate. Finally, importance of performance matrix analysis suggested that managers and policymakers should focus on effort expectancy, task characteristics, technology characteristics and supervisor support to boost employee intention to adopt technology and employee job performance.
\end{abstract}

Keywords: employee job performance, innovation valance, intention to adopt technology, moderating analysis, structural equation modelling, supervisory support.

Introduction. The use of information technology has become an essential and pervasive technique which is being used by individual, organizations and countries for their growth and prosperity. According to (Isaac, et al., 2019) asserted that internet technology has changed the organizational learning and implementation process. Several other studies revealed that the use of information technology in organizations augment employee productivity and job performance (Al-Alawi \& Al-Bassam, 2019; Samar Rahi, et al., 2020). Therefore, the diffusion of information technology is at its initial stages and organizations have failed to adopt information technology (Al-Alawi \& Al-Bassam, 2019; Samar Rahi et al., 2020). Thus, the present study extends the unified theory of acceptance and use of technology (UTAUT) with task technology fit (TTF) in order to examine how underpinning factors impact on employee intention to adopt information technology and enhance employee job performance. The extension of the unified theory of acceptance and use of technology is in line with (Samar \& Abd. Ghani, 2019; Samar \& Mazuri, 2019). A unified theory of acceptance and use of technology was introduced by (Venkatesh, et al., 2003) and incorporate four core factors namely performance expectancy, effort expectancy, social influence and facilitating condition.

The unified theory of acceptance and use of technology is extended in employee intention to adopt technology and employee job performance context with task technology fit theory (TTF). Previous studies have confirmed a significant influence of task technology fit factors on employee intention and productivity (Oliveira, et al., 2014; Tam \& Oliveira, 2016; Zhou, Lu, \& Wang, 2010). According to (Goodhue and Thompson,1995) task technology model helps individual to understand information system and individual performance. Thus, the current study incorporates two main constructs of task technology fit namely task

Cite as: Alyoubi, B. A., Yamin, M. A. Y. (2019). The Impact of Task Technology Fit on Employee Job Performance. Marketing and Management of Innovations, 4, 140-159. http://doi.org/10.21272/mmi.2019.4-12 
characteristics and technical characteristics. Aside from unified theory extension, the moderating role of supervisor support was also added between employee intention to adopt technology and employee job performance. Thus, factors underpinned two well-known information system (IS) theories including UTAUT and TTF were investigated in employee intention to adopt technology and job performance context. This study significantly contributes to information system literature and provides a guideline to managers and policymakers that how to enhance employee productivity and performance while using information technology in public sector organizations.

Literature Review. Unified Theory of Acceptance and Use of Technology (UTAUT). There are several research models that discuss information system and technology adoption trend among users. These models include technology acceptance model (TAM), the theory of Reasoned Action (TRA) and theory of planned behaviour (TPB) (Ajzen, 1991; Davis, et al., 1989; Fishbein \& Ajzen, 1975). According to (Venkatesh, et al. 2003) postulated that earlier theories have been conducted in voluntarily context and ignored the organizational context. Thus, it is important to introduce a unified theory which focuses on organizational adoption view instead of individual user adoption. In this essence, Venkatesh et al. (2003a) piloted longitudinal field research in mandatory context and introduced a new theory namely unified theory of acceptance and use of technology (UTAUT). The unified theory of acceptance and use of technology incorporates four exogenous constructs namely performance expectancy, effort expectancy, social influence and facilitating condition. According to Venkatesh et al. (2003a) performance expectancy, effort expectancy, social influence and facilitating condition have a significant influence on employee intention to adopt the technology. The detail of these variables is given in the following sections.

Performance Expectancy (PER). Performance expectancy is described as «the degree wherein an individual believes that using the system will help him/her to attain gains in job performance» (Samar Rahi, 2019; Venkatesh et al., 2003b). In organizational context performance expectancy is seen as employees performance expectation while using of organizational online system (Ling Keong, et al., 2012; Virdyananto, et al., 2016). A study conducted by (Brown, et al., 2010) investigates employee behaviour towards the adoption of technology in Finland and revealed that performance expectancy is significantly influenced by employee intention to adopt the technology. It is argued that the more employee expects performance while using technology, the more likely that they will adopt the existing technology (Venkatesh \& Davis, 2000). Therefore and backup with (Brown et al., 2010; Ling Keong et al., 2012; Venkatesh \& Davis, 2000; Virdyananto et al.,2016; Samar Rahi,2019; Venkatesh et al., 2003) performance expectancy is proposed as:

$\mathrm{H} 1$ : Performance expectancy has a positive effect on employee intention to adopt the technology.

Effort Expectancy (EEX). Effort expectancy is defined as «the degree of ease associated with the use of the system» (Venkatesh et al., 2003b). According to (Brown et al., 2010) postulated that in technology adoption context effort expectancy is the extent wherein user expect that use of information system will be free of effort. Similarly, earlier studies have confirmed that if technology use takes less effort, the more user intention is towards the adoption of information technology (Brown et al., 2010; Venkatesh et al., 2003b). Authors like Brown et al. (2010) had confirmed the direct influence of effort expectancy on employee intention to adopt the technology. According to Zhou et al. (2010) verified that when the user feels that use of technology is easy and does not require much effort, they would have high chances to adopt information system. Thus, effort expectancy is hypothesized as:

$\mathrm{H} 2$ : Effort expectancy has a positive effect on employee intention to adopt the technology.

Social Influence (SIN). Within the unified theory of acceptance and use of technology social influence is outlined as the third most important exogenous construct that influence on user intention to adopt the technology. Social influence is defined as «the degree where an individual perceives that important others believe he/she should use the new system» (Venkatesh et al., 2003a). It is said that individual intention is influenced by the surrounding people and environment (Samar Rahi, 2019). Thus, it is projected that an 
employee can influence others to use the information system. A study conducted by (Ling Keong et al.,2012) clearly showed a significant impact of social influence on user intention to adopt the technology. Therefore, it is confirmed that social influence positively influences on employee intention to adopt information system (Brown et al., 2010; Ling Keong et al., 2012; Samar Rahi, 2019; Venkatesh et al., 2003b). Hence, we derived the following hypothesis:

$\mathrm{H} 3$ : Social Influence has a positive effect on employee intention to adopt the technology.

Facilitating Conditions (FCC). The construct facilitating conditions is seen as «the degree to which an individual believes that an organizational and technical infrastructure exists to support the use and use of information system» (Venkatesh et al., 2003a). In an organizational context, (Ling Keong et al., 2012) confirmed the significant impact of facilitating condition on employee intention to adopt information technology. There are also some other studies that highlight the importance of facilitating condition in the adoption of technology (Martins, et al., 2014; Venkatesh, et al., 2012). The author like (Ling Keong et al., 2012) stated that employee who are new they need guidance and technical assistance to use information technology. It is also argued that organization having technical infrastructure for initial usage have more chance that employee will adopt the technology (Ling Keong et al., 2012; Venkatesh et al., 2012; Martins et al., 2014). Therefore and following the above arguments we proposed facilitating condition as:

$\mathrm{H} 4$ : Facilitating conditions has a positive effect on employee intention to adopt the technology.

Task technology fit theory (TTF). The importance of task technology fit theory is highlighted in earlier studies (Oliveira et al., 2014; Tam \& Oliveira, 2016; Zhou et al., 2010). According to (Goodhue and Thompson,1995) task technology model helps individual to understand information system and individual performance. This study incorporates two main constructs of task technology fit namely task characteristics and technical characteristics. The detail of these constructs is described in the following sections.

Task Characteristics (TAC). The first construct of task technology fit is task characteristics and defined as «the actions carried out by individuals in turning inputs into outputs» (Goodhue \& Thompson, 1995). Task technology fit model claims that the user will only accept information technology if it is useful and improve his/her performance. Authors like (Oliveira et al.,2014) postulated that task characteristics directly link to user actions to perform a task using the information system. It is also stated that task technology fit model roots embedded in information success dimensions and directly influence user behaviour to adopt the technology(Zhou et al., 2010). Earlier studies have confirmed a significant relationship between task characteristics and employee intention to adopt internet technology (Oliveira et al., 2014; Tam \& Oliveira, 2016; Zhou et al., 2010). Thus, task characteristic in information system context is proposed as:

$\mathrm{H} 5$ : Task characteristic has a positive effect on performance expectancy.

H6: Task characteristic has a positive effect on effort expectancy.

H7: Task characteristic has a positive effect on employee intention to adopt the technology.

Technology Characteristics (TCC). The second construct of task technology fit model is technology characteristics (Goodhue, 1995). Technology characteristics is defined as «technology which is used by individuals to perform their tasks» (Goodhue \& Thompson, 1995). Earlier studied have confirmed a strong linkage between technology characteristics and use of internet technology in organizations (Oliveira et al., 2014; Tam \& Oliveira, 2016; Zhou et al., 2010). A recent study conducted by (Tam and Oliveira,2016) confirmed that technology characteristics influence on user intention to adopt technology and enhance job performance. Similarly, (Oliveira et al.,2014) had integrated unified theory of acceptance and use of technology and task technology fit model. The results of (Oliveira et al.,2014) revealed the substantial impact on user intention to adopt technology while using TTF \& UTAUT factors. Following the above arguments we derived the following hypothesis:

H8: Technology Characteristic has a positive effect on performance expectancy.

$\mathrm{H} 9$ : Technology Characteristic has a positive effect on effort expectancy. 
H10: Technology Characteristic has a positive effect on employee intention to adopt the technology.

Innovation Valance (INV). Innovation valance is defined as «the degree wherein employee shows a positive attitude towards adoption of information technology» (Armenakis, et al., 2007; Lokuge, et al., 2018). Innovation valance is actually represented three perspectives of user behaviour namely motivation, empowerment and attitude (Lokuge et al., 2018). According to (Lokuge et al.,2018) employee motivation, positive attitude and empowerment are the core factors that influence employee intention to adopt technology at an organizational level. It is also said that motivation may be elevated looking at dynamic changes in the industry (Lokuge et al., 2018). Similarly, employee positive attitude motivates them to adopt an information system. Finally, the empowerment dimension reflects that the employee has direct access to the information system in the organization. The present study concludes these three dimensions into innovation valance and examines the role of innovation valance in employee intention to adopt information technology in the organizational context. Previous literature established that innovation valance had a significant influence on user intention to adopt the technology (Armenakis et al., 2007; Lokuge et al., 2018; Ozturk, et al., 2017; Sarker, Valacich, \& Sarker, 2005). Hence, the following hypothesis is derived:

$\mathrm{H} 11$ : Innovative valance has a positive effect on employee intention to adopt the technology.

Intention to adopt technology and employee job performance. There are several studies that used intention to adopt technology as an outcome variable to investigate the role of technology in organizational operations (Brown et al., 2010); (Martins et al., 2014; Samar and Mazuri, 2019). However, contrary to traditional studies the present study augments the body of knowledge in information system research by incorporating employee job performance as an outcome variable. In this study employee job performance is predicted by employee intention to adopt information technology and in line with previous literature (Ahmad \& Marinah, 2013; Dewett, 2007; Ha \& Lo, 2018; Hanaysha, 2016; Hirst, Van Dick, \& Van Knippenberg, 2009; Lockwood, 2007; Marsick \& Watkins, 1999; Wang \& Noe, 2010). Employee job performance is described as «the extent wherein system usage increases the quality of work by helping to complete the task quickly, allow control over work, improve job performance, eliminate errors and boost effectiveness on the job» (Makokha \& Ochieng, 2014; Wang \& Liao, 2008). Earlier studies have confirmed that individual intention to adopt technology impact on employee job performance impact (Daud Norzaidi, et al.,2007; Hung, Sun, and Yu,2015; loimo and Aronson,2003; Makokha and Ochieng,2014; Wang and Liao,2008; Yen, et al.,2010). Thus, employee job performance is proposed as:

H12: Employee intention to adopt technology has a positive effect on employee job performance.

Supervisory Support and employee job performance. In organizational context supervisor support is wherein employee difficulties, task organizations, scheduling accommodation, family needs, ideas and advice are carefully acknowledged by the supervisor for employee well-being (Bergiel, et al., 2009). There are several factors that influence on employee job performance therefore the role of supervisor support is essential for employee performance (Bergiel et al., 2009). Supervisor support has been identified an important factor that influences on employee job performance (Bergiel et al., 2009; Hanaysha, 2016; Marsick \& Watkins, 1999; Mohammad Ali, 2018). According to (Hanaysha,2016) postulated that attractive place and supervisor support enhance employee satisfaction and boost employee job performance. Therefore, the current study extends the body of knowledge in this context and underpinned supervisor support as a moderating variable. Supervisor support is proposed between the relationship of employee intention to adopt technology and employee job performance in such a way that the positive relationship between employee intention to adopt technology and employee job performance will be stronger when supervisory support is higher. Earlier studies have confirmed that supervisor support influence on employee intention to adopt information technology and employee job performance (Aldholay, et al., 2018; Bandura, et al., 1999; Choi, 2004; Makokha \& Ochieng, 2014; Samar Rahi \& Abd. Ghani, 2018; Tierney \& Farmer, 2002; Y.-S. Wang \& Liao, 2008; Yu, 2012). Thus, supervisor support is hypothesized as:

$\mathrm{H13}$ : The positive relationship between intention to adopt technology and employee job performance will be stronger when supervisory support is higher. 
Methodology and research methods. Instruments development. The research model as shown in Figure 1 is based on a quantitative research approach and needed to be analyzed with statistical approaches. In this essence, a data set is required for inferential analysis. Thus, a survey questionnaire was developed which contains two types of questions including demographics and scale items. The demographic part of the questionnaire includes the respondent's age, gender and education. The second part of the questionnaire includes instrument items to measure the respondent's observations. All scale items were adopted from literature and then adapted into the current research context. In addition to that scale, items were measured using a seven-point Likert scale ranging 1 for «strongly disagree» to 7 for «strongly agree» (Rahi, 2017). Measurement items for performance expectancy, effort expectancy, social influence, and facilitating conditions were adopted from (Samar Rahi et al., 2019) and then adapted into employee job performance setting. Construct items for intention to adopt technology were adopted from (Samar Rahi,2019) and then adapted into the current research context. Concerning with task technology fit theory (TTF), both constructs items including task characteristics and technology characteristics were adopted from (Daud Norzaidi et al., 2007) and then adapted into current research context. Innovative valance items were adopted from (Lokuge, et al., 2019) and later adapted in the organizational scenario. Measurement items for a construct such as supervisor support were adapted from (Bergiel et al., 2009). Finally, items scales for employee job performance were adopted from (Bergiel et al., 2009). The reliability and validity of these items were tested with structural equation modelling (SEM).

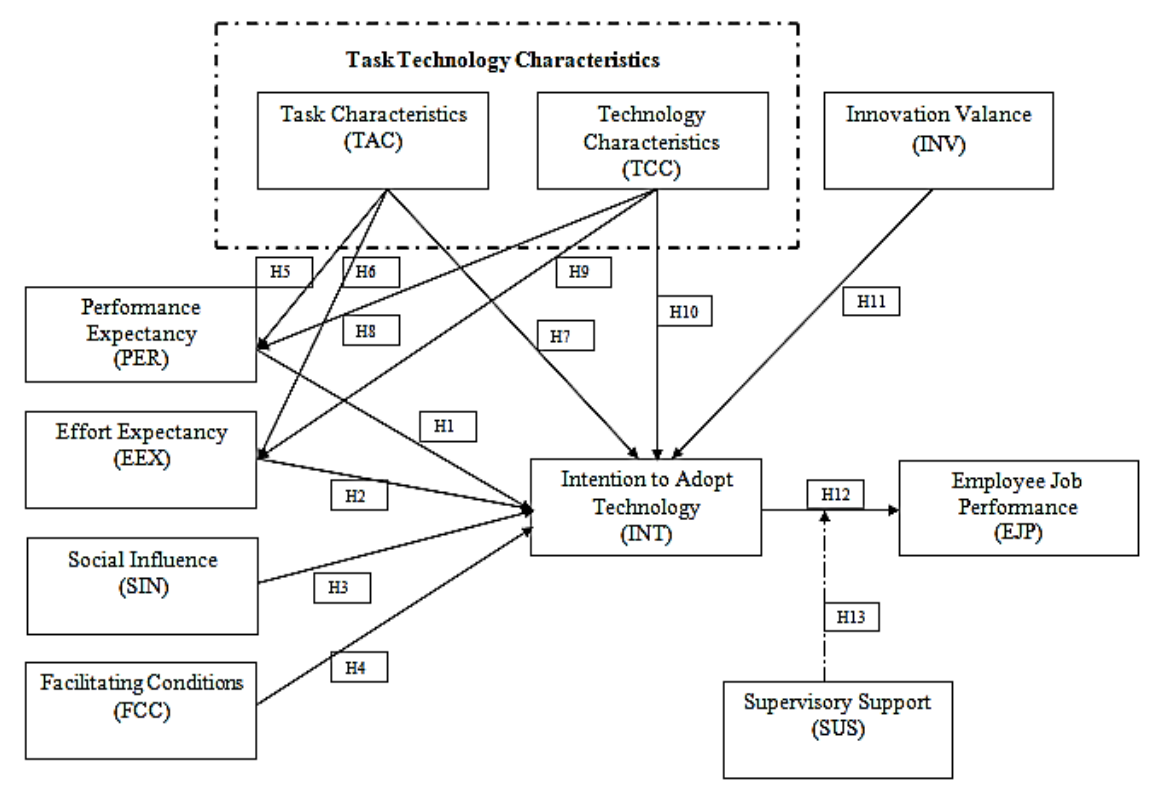

Figure 1. The proposed research model

Data collection and sampling. In order to test the proposed research model, the respondent's observations are required. Therefore, an administrative survey was conducted towards Saudi public organizations. A survey questionnaire was distributed among middle-level managers working in HR departments of Saudi Public organizations. The inclusion criterion was that HR managers must have knowledge about online services offering by respective organizations to employees. The overall objective was to identify the role of technology on employee job performance. Prior to questionnaire distribution, 
sample size was selected following guideline argued (S Rahi,2017) that study aims to conduct factor analysis is required to have 300 sample size.

To achieve an appropriate number of responses 500 questionnaires were distributed among HR managers of Public sector organizations in Saudi Arabia. For questionnaire distribution convenience sampling approach adopted. According to (R. Samar and Mazuri, 2019b) convenience sampling approach is appropriate to be taken into consideration wherein a list of the respondents are not available in advance. In addition to that convenience sampling approach helps to obtain correct observation from actual respondents (Samar Rahi et al., 2020). Another advantage of a convenience sampling approach is veracity in data set which reveal interesting findings (Samar Rahi \& Abd. Ghani, 2019b). In response to administrative survey 398 questionnaires were returned with a response rate of $79.6 \%$. Among 398 questionnaires 38 were discarded due to inappropriate answers in line with (Samar Rahi and Abd. Ghani, 2019c) and 358 questionnaires were finally used for structural equation modelling.

Common method variance bias (CMV). The current study is based on quantitative research method which further followed the positivist paradigm. Thus it is important that research should be free from any error or common method variance biases. Common method variance bias occurs when data is collected using a single source both for endogenous and exogenous variables. Therefore, the present study test common method variance bias using Harman's single factor test (Podsakoff, et al., 2003). According to (Podsakoff et al., 2003) the maximum co-variance explained by the first factor should be less than $50 \%$. Results showed that the maximum co-variance explained by the first factor was only $23.19 \%$ which is less than the threshold value of $50 \%$ (Podsakoff et al., 2003). These findings confirmed that the current study data set is free from common method variance bias and appropriate for structural equation modelling.

Results. The research model is tested with structural equation modelling (SEM). Structural equation modelling (SEM) «is a statistical technique for testing and estimating causal relations using a combination of statistical data and qualitative causal assumptions» (S. Rahi, 2017; R. Samar \& Mazuri, 2019a). For structure equation model estimation, a two-stage approach was used as suggested by (S. Rahi,2017) and (Anderson and Gerbing,1988). The first stage evaluates construct reliability and validity and known as a measurement model. Therefore, the second stage is entitled structural model and estimate constructs path in order to accept or reject a hypothesis. For structural equation model computation Smart PLS 3.2.8 software is used (S. Rahi, 2017; Ringle, Wende, \& Becker, 2015).

Measurement model. The measurement model includes an assessment of construct reliability, indicator reliability, convergent validity and discriminant validity of the constructs. Construct reliability the values of Cronbach's (a) and Composite Reliability (CR) were estimated. Therefore, the convergent validity of the construct was tested with the average variance extracted (AVE). In order to achieve construct reliability, the criterion is that the values of Cronbach's alpha and composite reliability should be greater than 0.70 as suggested by (S. Rahi,2017). Findings of the PLS algorithm showed that all constructs alpha values and composite reliability were greater than threshold values 0.70 thus confirming construct reliability. For indicator reliability criterion is that indicator loadings should be greater than 0.60 as recommended by (S. Rahi,2017). Results showed that all indicator loadings were greater than 0.60 , and confirmed adequate reliability of the indicators. In addition to that, the convergent validity of the constructs was checked with average variance extracted following criterion that the values should be greater than 0.50 following guideline provided by (Fornell and Larcker,1981b) and (S. Rahi,2017). Results showed that all the values of AVE were greater than threshold values 0.50 , indicated sufficient convergent validity of the constructs.

Table 1 showed the results of the measurement model which includes values of Cronbach's Alpha (a), Composite reliability (CR), factor loadings and average variance extract (AVE) values of the constructs. 
Table 1. The measurement model

\begin{tabular}{|c|c|c|c|c|}
\hline Constructs items & Loadings & (a) & CR & AVE \\
\hline \multicolumn{5}{|c|}{ Effort Expectancy (EEX) } \\
\hline $\begin{array}{l}\text { EEX1: In my organization my interaction with information system } \\
\text { would be clear and understandable. }\end{array}$ & 0.976 & 0.968 & 0.979 & 0.941 \\
\hline $\begin{array}{l}\text { EEX2: In my organization learning to operate information system } \\
\text { would be easy for me. }\end{array}$ & 0.958 & & & \\
\hline $\begin{array}{l}\text { EEX3: In my organization it is easy for me to become skillful by } \\
\text { using information system. }\end{array}$ & 0.975 & & & \\
\hline \multicolumn{5}{|c|}{\begin{tabular}{|l} 
Employee Job Performance (EJP) \\
\end{tabular}} \\
\hline EJP1: Using technology my task quickly accomplished & 0.941 & 0.894 & 0.934 & 0.826 \\
\hline EJP2: Using technology my work quality improved & 0.874 & & & \\
\hline EJP3: Using technology my job performance improved & 0.910 & & & \\
\hline \multicolumn{5}{|c|}{ Facilitating Conditions (FCC) } \\
\hline $\begin{array}{l}\text { FCC1: I have the resources necessary to use the information } \\
\text { system. }\end{array}$ & 0.801 & 0.802 & 0.871 & 0.628 \\
\hline $\begin{array}{l}\text { FCC2: Information system is compatible with other technologies } \\
\text { I use. }\end{array}$ & 0.776 & & & \\
\hline $\begin{array}{l}\text { FCC3: I have the knowledge necessary to use the information } \\
\text { system. }\end{array}$ & 0.811 & & & \\
\hline $\begin{array}{l}\text { FCC4: A specific person is available for assistance of information } \\
\text { system difficulties. }\end{array}$ & 0.781 & & & \\
\hline \multicolumn{5}{|c|}{ Intention to Adopt Technology (INT) } \\
\hline INT1: I intend to use information system in the next months. & 0.856 & 0.856 & 0.912 & 0.776 \\
\hline INT2: I plan to use information system in the next months. & 0.892 & & & \\
\hline INT3: I predict I would use information system in the next months. & 0.895 & & & \\
\hline \multicolumn{5}{|c|}{ Innovation Valance (INV) } \\
\hline $\begin{array}{l}\text { INV1: I am usually the first to try out new information } \\
\text { technologies. }\end{array}$ & 0.847 & 0.775 & 0.853 & 0.594 \\
\hline $\begin{array}{l}\text { INV2: If I heard about a new information technology, I would look } \\
\text { for ways to experiment with it. }\end{array}$ & 0.776 & & & \\
\hline $\begin{array}{l}\text { INV3: If I heard about a new human resource information system, } \\
\text { I would look for ways to experiment with it. }\end{array}$ & 0.766 & & & \\
\hline $\begin{array}{l}\text { INV4: I like to experiment with new human resource information } \\
\text { system technologies. }\end{array}$ & 0.684 & & & \\
\hline \multicolumn{5}{|c|}{ Performance Expectancy (PER) } \\
\hline $\begin{array}{l}\text { PER1: In my organization information system is useful to carry } \\
\text { out my tasks. }\end{array}$ & 0.905 & 0.899 & 0.929 & 0.767 \\
\hline $\begin{array}{l}\text { PER2: I think that using information system would increase my } \\
\text { productivity. }\end{array}$ & 0.866 & & & \\
\hline $\begin{array}{l}\text { PER3: I think that using information system would improve my } \\
\text { performance. }\end{array}$ & 0.872 & & & \\
\hline $\begin{array}{l}\text { PER4: I think that using information system would enable me to } \\
\text { conduct tasks more quickly. }\end{array}$ & 0.860 & & & \\
\hline \multicolumn{5}{|c|}{ Social Influence (SIN) } \\
\hline $\begin{array}{l}\text { SINF1: People who are important to me think that I should use } \\
\text { Information System. }\end{array}$ & 0.867 & 0.881 & 0.927 & 0.808 \\
\hline $\begin{array}{l}\text { SINF2: People in my environment who use Information System } \\
\text { services have a high profile. }\end{array}$ & 0.929 & & & \\
\hline $\begin{array}{l}\text { SINF3: Having Information System services is a status of symbol } \\
\text { in my company environment. }\end{array}$ & 0.899 & & & \\
\hline
\end{tabular}


Continued Table 1

\begin{tabular}{|c|c|c|c|c|}
\hline Constructs items & Loadings & (a) & CR & AVE \\
\hline \multicolumn{5}{|c|}{ Supervisory Support (SUS) } \\
\hline $\begin{array}{l}\text { SUS1: In my organization my supervisor praises employees who } \\
\text { do well work. }\end{array}$ & 0.816 & 0.798 & 0.882 & 0.713 \\
\hline $\begin{array}{l}\text { SUS2: My supervisor praises those who prefer to use information } \\
\text { system. }\end{array}$ & 0.834 & & & \\
\hline $\begin{array}{l}\text { SUS3: My supervisor praises employee who are good in use of } \\
\text { human resource information system }\end{array}$ & 0.882 & & & \\
\hline \multicolumn{5}{|l|}{ Task Characteristics (TAC) } \\
\hline $\begin{array}{l}\text { TAC1: Using information system I often handle the ad hoc and } \\
\text { non-routine jobs. }\end{array}$ & 0.910 & 0.890 & 0.923 & 0.750 \\
\hline $\begin{array}{l}\text { TAC2: Using information system I often deal with a high difficulty } \\
\text { level task. }\end{array}$ & 0.840 & & & \\
\hline $\begin{array}{l}\text { TAC3: Using information system I often get the business } \\
\text { questions that never been asked before }\end{array}$ & 0.939 & & & \\
\hline $\begin{array}{l}\text { TAC4: I often get the business questions that never been asked } \\
\text { before and it enhance my job performance }\end{array}$ & 0.763 & & & \\
\hline \multicolumn{5}{|c|}{ Technology Characteristics (TCC) } \\
\hline TCC1: I feel online information system provide real time services & 0.822 & 0.920 & 0.944 & 0.808 \\
\hline $\begin{array}{l}\text { TCC2: I feel online information system easily accessible at any } \\
\text { time required }\end{array}$ & 0.948 & & & \\
\hline $\begin{array}{l}\text { TCC3: I feel human resource information system provide a } \\
\text { secure service. }\end{array}$ & 0.931 & & & \\
\hline $\begin{array}{l}\text { TCC4: I feel online information system provide a secure service } \\
\text { to employees. }\end{array}$ & 0.888 & & & \\
\hline
\end{tabular}

Note: $\mathrm{CR}=$ (Square of the summation of the factor loadings) / [(square of the summation of the factor loadings) + (square of the summation of the error variances)] AVE = (summation of squared factor loadings) / (summation of squared factor loadings) (summation of error variances).

Sources: developed by the authors.

In order to examine whether constructs items show a distinct concept to differentiate one construct with another construct the discriminant validity of the construct was checked. According to (Samar Rahi and Abd. Ghani,2019a) construct should be discriminant to achieve construct validity. The discriminant validity of the constructs can be examined in three ways including Fornell and Larcker criterion, Cross loadings and Heterotrait-Monotrait Ratio (HTMT). At first, this study estimates the discriminant validity of the constructs following criterion suggested by (Fornell and Larcker,1981a). This method suggested that «the square root of AVE should be greater than the correlations between the constructs indicate adequate discriminant validity of the constructs» (Fornell \& Larcker, 1981a). The results of the discriminant validity can be seen in Table 2 which showed that the square root of average variance extracted (bold) was greater than the correlations between the constructs and confirmed that construct was discriminant.

Earlier studies argued that Fornell and Larcker's criterion is not satisfactory to confirm discriminant validity of the constructs (Samar Rahi \& Abd. Ghani, 2018b; S Rahi, et al., 2018). Thus another method namely cross-loadings was used to confirm whether construct discriminant or not. In order to achieve adequate discriminant validity of the constructs using cross-loading method, the criterions is that indicator's outer loadings should be higher than the other constructs loadings (Fornell \& Larcker, 1981a). Findings of the measurement model revealed that indicator's outer loadings (in italic) are higher than the 
other constructs loadings which indicate that discriminant validity of the constructs. The results of the cross-loadings are depicted in Table 3.

Table 2. Discriminant validity using Fornell and Larcker's criterion

\begin{tabular}{|c|c|c|c|c|c|c|c|c|c|c|}
\hline$\#$ & EEX & EJP & FCC & INT & INV & PER & SINF & SUS & TAC & TCC \\
\hline EEX & $\mathbf{0 . 9 7 0}$ & & & & & & & & & \\
\hline EJP & 0.281 & $\mathbf{0 . 9 0 9}$ & & & & & & & & \\
\hline FCC & 0.351 & 0.244 & $\mathbf{0 . 7 9 2}$ & & & & & & & \\
\hline INT & 0.774 & 0.405 & 0.436 & $\mathbf{0 . 8 8 1}$ & & & & & & \\
\hline INV & 0.030 & 0.039 & 0.082 & 0.150 & $\mathbf{0 . 7 7 0}$ & & & & & \\
\hline PER & 0.510 & 0.362 & 0.306 & 0.659 & 0.099 & $\mathbf{0 . 8 7 6}$ & & & & \\
\hline SINF & 0.323 & 0.214 & 0.223 & 0.459 & 0.002 & 0.298 & $\mathbf{0 . 8 9 9}$ & & & \\
\hline SUS & -0.019 & 0.133 & 0.012 & -0.020 & -0.001 & 0.057 & 0.016 & $\mathbf{0 . 8 4 4}$ & & \\
\hline TAC & 0.297 & 0.317 & 0.227 & 0.467 & 0.106 & 0.460 & 0.273 & 0.053 & $\mathbf{0 . 8 6 6}$ & \\
\hline TCC & 0.287 & 0.210 & 0.147 & 0.437 & 0.108 & 0.380 & 0.182 & -0.104 & 0.254 & $\mathbf{0 . 8 9 9}$ \\
\hline
\end{tabular}

Note: Bold values indicate the square root of AVE of each construct.

Sources: developed by the authors.

Table 3. Cross loadings criterion

\begin{tabular}{|c|c|c|c|c|c|c|c|c|c|c|}
\hline$\#$ & EEX & EJP & FCC & INT & INV & PER & SINF & SUS & TAC & TCC \\
\hline EEX1 & 0.976 & 0.283 & 0.328 & 0.755 & 0.041 & 0.528 & 0.306 & -0.018 & 0.299 & 0.292 \\
\hline EEX2 & 0.958 & 0.270 & 0.348 & 0.752 & 0.000 & 0.472 & 0.315 & -0.028 & 0.294 & 0.271 \\
\hline EEX3 & 0.975 & 0.265 & 0.344 & 0.744 & 0.046 & 0.482 & 0.319 & -0.009 & 0.269 & 0.270 \\
\hline EJP1 & 0.254 & 0.941 & 0.242 & 0.350 & 0.023 & 0.324 & 0.188 & 0.112 & 0.244 & 0.153 \\
\hline EJP2 & 0.259 & 0.874 & 0.219 & 0.418 & 0.056 & 0.374 & 0.213 & 0.108 & 0.376 & 0.280 \\
\hline EJP3 & 0.252 & 0.910 & 0.201 & 0.329 & 0.024 & 0.279 & 0.179 & 0.145 & 0.232 & 0.128 \\
\hline FCC1 & 0.291 & 0.262 & 0.801 & 0.360 & 0.066 & 0.256 & 0.166 & 0.007 & 0.146 & 0.166 \\
\hline FCC2 & 0.283 & 0.212 & 0.776 & 0.335 & 0.056 & 0.272 & 0.161 & 0.009 & 0.125 & 0.159 \\
\hline FCC3 & 0.293 & 0.195 & 0.811 & 0.337 & 0.044 & 0.223 & 0.187 & -0.015 & 0.198 & 0.062 \\
\hline FCC4 & 0.244 & 0.102 & 0.781 & 0.347 & 0.092 & 0.220 & 0.192 & 0.036 & 0.249 & 0.077 \\
\hline INT1 & 0.913 & 0.269 & 0.364 & 0.856 & 0.101 & 0.573 & 0.332 & -0.035 & 0.319 & 0.342 \\
\hline INT2 & 0.545 & 0.435 & 0.379 & 0.892 & 0.146 & 0.567 & 0.413 & 0.014 & 0.471 & 0.435 \\
\hline INT3 & 0.562 & 0.374 & 0.410 & 0.895 & 0.152 & 0.602 & 0.473 & -0.029 & 0.452 & 0.380 \\
\hline INV1 & 0.053 & 0.024 & 0.063 & 0.145 & 0.847 & 0.061 & -0.001 & 0.057 & 0.101 & 0.071 \\
\hline INV2 & -0.032 & 0.067 & 0.103 & 0.105 & 0.776 & 0.065 & 0.032 & 0.029 & 0.061 & 0.145 \\
\hline INV3 & 0.035 & 0.019 & 0.053 & 0.120 & 0.766 & 0.089 & -0.015 & -0.079 & 0.086 & 0.087 \\
\hline INV4 & 0.026 & 0.012 & 0.027 & 0.076 & 0.684 & 0.105 & -0.011 & -0.030 & 0.075 & 0.023 \\
\hline PER1 & 0.607 & 0.275 & 0.261 & 0.586 & 0.054 & 0.905 & 0.224 & 0.029 & 0.333 & 0.315 \\
\hline PER2 & 0.320 & 0.383 & 0.289 & 0.592 & 0.147 & 0.866 & 0.287 & 0.069 & 0.495 & 0.387 \\
\hline PER3 & 0.351 & 0.363 & 0.299 & 0.592 & 0.087 & 0.872 & 0.347 & 0.053 & 0.476 & 0.312 \\
\hline PER4 & 0.545 & 0.222 & 0.212 & 0.532 & 0.045 & 0.860 & 0.164 & 0.046 & 0.273 & 0.309 \\
\hline SINF1 & 0.329 & 0.208 & 0.202 & 0.415 & -0.001 & 0.276 & 0.867 & 0.035 & 0.284 & 0.134 \\
\hline SINF2 & 0.279 & 0.181 & 0.213 & 0.422 & -0.016 & 0.275 & 0.929 & 0.010 & 0.239 & 0.188 \\
\hline SINF3 & 0.261 & 0.189 & 0.185 & 0.399 & 0.023 & 0.252 & 0.899 & -0.001 & 0.212 & 0.170 \\
\hline SUS1 & -0.022 & 0.116 & -0.005 & -0.030 & 0.010 & 0.051 & 0.017 & 0.816 & 0.031 & -0.093 \\
\hline SUS2 & 0.023 & 0.105 & 0.031 & 0.020 & 0.037 & 0.067 & 0.009 & 0.834 & 0.058 & -0.094 \\
\hline SUS3 & -0.045 & 0.115 & 0.006 & -0.036 & -0.046 & 0.029 & 0.015 & 0.882 & 0.046 & -0.078 \\
\hline TAC1 & 0.245 & 0.280 & 0.209 & 0.395 & 0.104 & 0.387 & 0.201 & 0.063 & 0.910 & 0.221 \\
\hline TAC2 & 0.354 & 0.278 & 0.242 & 0.493 & 0.090 & 0.477 & 0.327 & 0.045 & 0.840 & 0.224 \\
\hline TAC3 & 0.229 & 0.294 & 0.171 & 0.411 & 0.114 & 0.396 & 0.231 & 0.049 & 0.939 & 0.265 \\
\hline
\end{tabular}


Continued Table 3

\begin{tabular}{|c|c|c|c|c|c|c|c|c|c|c|}
\hline$\#$ & EEX & EJP & FCC & INT & INV & PER & SINF & SUS & TAC & TCC \\
\hline TAC4 & 0.136 & 0.239 & 0.135 & 0.248 & 0.047 & 0.277 & 0.130 & 0.019 & $\mathbf{0 . 7 6 3}$ & 0.145 \\
\hline TCC1 & 0.374 & 0.128 & 0.138 & 0.376 & 0.095 & 0.349 & 0.161 & -0.093 & 0.140 & $\mathbf{0 . 8 2 2}$ \\
\hline TCC2 & 0.228 & 0.228 & 0.151 & 0.435 & 0.112 & 0.351 & 0.156 & -0.091 & 0.286 & $\mathbf{0 . 9 4 8}$ \\
\hline TCC3 & 0.240 & 0.227 & 0.115 & 0.414 & 0.087 & 0.345 & 0.184 & -0.091 & 0.262 & $\mathbf{0 . 9 3 1}$ \\
\hline TCC4 & 0.162 & 0.173 & 0.122 & 0.331 & 0.095 & 0.312 & 0.152 & -0.099 & 0.226 & $\mathbf{0 . 8 8 8}$ \\
\hline
\end{tabular}

Sources: developed by the authors.

More recently Heterotrait-Monotrait Ratio (HTMT) method was introduced by (Kline, 2011) and Gold and Arvind Malhotra (2001) to check the constructs discriminant validity. According to (Samar, et al. ,2017) Fornell and Larcker's criterion and cross-loading method may appropriate in a data set where data set had achieved normality. Therefore, if the data is not normal it is important to compute the discriminant validity of the construct using Heterotrait-Monotrait Ratio (HTMT) (Samar et al., 2017). In order to achieve Heterotrait-Monotrait Ratio (HTMT), the criterion is that HTMT values should be less than HTMT 0.85 or 0.90 as suggested by (Kline,2011) and (Gold and Arvind Malhotra,2001). Results of Heterotrait-Monotrait Ratio revealed that all HTMT values were less than HTMT 0.85 or $0.90($ Kline,2011) and Gold and Arvind Malhotra (2001). These findings confirmed that constructs have adequate discriminant validity to measure a distinct concept.

Table 4 shows the values of Heterotrait-Monotrait Ratio (HTMT).

Table 4. Heterotrait-Monotrait Ratio (HTMT)

\begin{tabular}{|c|c|c|c|c|c|c|c|c|c|c|}
\hline Variable & EEX & EJP & FCC & INT & INV & PER & SINF & SUS & TAC & TCC \\
\hline EEX & NA & & & & & & & & & \\
\hline EJP & 0.302 & & & & & & & & & \\
\hline FCC & 0.398 & 0.286 & & & & & & & & \\
\hline INT & 0.840 & 0.463 & 0.526 & & & & & & & \\
\hline INV & 0.054 & 0.050 & 0.106 & 0.178 & & & & & & \\
\hline PER & 0.557 & 0.392 & 0.356 & 0.748 & 0.120 & & & & & \\
\hline SINF & 0.349 & 0.240 & 0.265 & 0.530 & 0.030 & 0.327 & & & & \\
\hline SUS & 0.041 & 0.158 & 0.050 & 0.045 & 0.080 & 0.067 & 0.029 & & & \\
\hline TAC & 0.300 & 0.347 & 0.258 & 0.514 & 0.121 & 0.484 & 0.289 & 0.061 & & \\
\hline TCC & 0.296 & 0.227 & 0.169 & 0.490 & 0.125 & 0.412 & 0.202 & 0.122 & 0.274 & NA \\
\hline
\end{tabular}

Note: Heterotrait-Monotrait Ratio (HTMT) discriminate at (HTMT <0.9/ HTMT <0.85).

Sources: developed by the authors.

Structural model. The measurement model confirmed the validity and reliability of the constructs therefore the significance of the relationship between the exogenous variable and endogenous variable is tested with a structural model. Structural model assessment includes evaluation of lateral multicollinearity, path-coefficients using beta values $\beta$, and corresponding t-values. In addition to that, the variance explained in the endogenous variable was also estimated with the coefficient of determination $R^{2}$. The lateral multicollinearity of the construct was estimated with variance inflation factors (VIF). The author like (S Rahi, et al., 2018) argued that the assessment of multicollinearity is important to make sure that the hypothesized relationship between two constructs is causally related and measure the same construct.

In order to confirm whether the underpinned constructs had adequate lateral multicollinearity, the values of variance inflation factors (VIF) were estimated following criterion that the variance inflation factors values should be less than 3.3 as recommended by (Samar Rahi, et al., 2019). Findings of the structural model revealed that all the VIF values with corresponding endogenous and exogenous variables 
were greater than 3.3 , confirmed that lateral multicollinearity is not a significant issue in this study. The results of lateral multicollinearity using variance inflation factors (VIF) are exhibited in Table 5.

Table 5. Lateral Multicollinearity Assessment

\begin{tabular}{|c|c|c|c|c|}
\hline Constructs & EEX & EJP & INT & PER \\
\hline Effort Expectancy (EEX) & & & 1.499 & \\
\hline Employee Job Performance (EJP) & & & & \\
\hline Facilitating Conditions (FCC) & & & 1.192 & \\
\hline Intention to Adopt Technology (INT) & & 1.000 & & \\
\hline Innovation Valance (INV) & & & 1.026 & \\
\hline Performance Expectancy (PER) & & & 1.699 & \\
\hline Social Influence (SIN) & & & 1.187 & \\
\hline Supervisory Support (SUS) & & 1.000 & & \\
\hline Technology Characteristics (TCC) & 1.069 & & 1.325 & 1.069 \\
\hline Task Characteristics (TAC) & 1.069 & & 1.203 & 1.069 \\
\hline
\end{tabular}

Sources: developed by the authors.

Hypothesis testing. The hypothesized relationships were examined with path coefficient, standard deviations, t-values and significance level. In order to compute t-statistics help was taken from a bootstrapping procedure. Bootstrapping analysis was conducted with re-sample 3,000 as suggested by (Rahi, 2018). Table 6 exhibits the results of hypotheses including path coefficient, standard deviations, tvalues and the significance level of the proposed relationship.

Table 6. Results of hypothesis

\begin{tabular}{|c|c|c|c|c|c|}
\hline Hypothesis & Relationship & Direct effect ( $\beta$ ) & SE & T-statistics & Result \\
\hline $\mathrm{H} 1$ & PER -> INT & 0.216 & 0.046 & $4.740^{\star \star \star}$ & Supported \\
\hline $\mathrm{H} 2$ & EEX -> INT & 0.504 & 0.046 & $10.942^{* * *}$ & Supported \\
\hline $\mathrm{H} 3$ & SINF -> INT & 0.153 & 0.032 & $4.730^{* * *}$ & Supported \\
\hline $\mathrm{H} 4$ & FCC $->$ INT & 0.108 & 0.028 & $3.925^{* \star *}$ & Supported \\
\hline $\mathrm{H} 5$ & TAC -> PER & 0.388 & 0.049 & $7.912^{* \star *}$ & Supported \\
\hline $\mathrm{H} 6$ & TAC -> EEX & 0.239 & 0.051 & $4.666^{* *}$ & Supported \\
\hline $\mathrm{H} 7$ & TAC -> INT & 0.110 & 0.039 & $2.852^{* *}$ & Supported \\
\hline $\mathrm{H} 8$ & TCC -> PER & 0.282 & 0.055 & $5.087^{* \star *}$ & Supported \\
\hline $\mathrm{H} 9$ & TCC $>>$ EEX & 0.226 & 0.056 & $4.029^{\star \star \star}$ & Supported \\
\hline $\mathrm{H} 10$ & TCC -> INT & 0.130 & 0.034 & $3.862^{\star \star \star}$ & Supported \\
\hline $\mathrm{H} 11$ & INV -> INT & 0.078 & 0.026 & $2.982^{\star \star}$ & Supported \\
\hline $\mathrm{H} 12$ & INT -> EJP & 0.408 & 0.059 & $6.974^{* * *}$ & Supported \\
\hline
\end{tabular}

Note: ${ }^{*} p<0.05 ;{ }^{* *} p<0.01 ;{ }^{* * *} p<0.001$ (one-tailed).

Sources: developed by the authors.

The results of the structural equation modelling indicate that user intention to adopt technology is jointly predicted by performance expectancy, effort expectancy, social influence, facilitating condition, task characteristics, technology characteristics and innovation valance and explained $R^{2} 77 \%$ variance in employee intention to adopt the technology. On the flip side employee job performance was predicted by intention to adopt technology and supervisor support and explained $R^{2} 20.6 \%$ variance in employee job performance. Findings revealed that performance expectancy significantly influences on intention to adopt technology and statistically significant $\mathrm{H1}$ : $(\beta=0.216$, t-value 4.740 , significance $p<0.001)$. Effort expectancy had shown significant influence on the intention to adopt technology and supported by $\mathrm{H} 1$ : 
( $\beta=0.504$, t-value 10.942, significance $p<0.001$ ). Similarly, social influence and facilitating condition had positive and significant influence on intention to adopt technology $(\beta=0.153$, t-value 4.730 , significance $p<0.001 ; \beta=0.108$, t-value 3.925, significance $p<0.001$ ) hence, confirming $\mathrm{H} 3$ and $\mathrm{H} 4$. Concerning with task technology fit, findings showed that both constructs task characteristics and technology characteristics had a significant relationship with intention to adopt the technology. Task characteristics significantly influence on performance expectancy, effort expectancy and intention to adopt technology and supported by $(\beta=0.388$, t-value 7.912, significance $p<0.001 ; \beta=0.239$, t-value 4.666, significance $p<$ $0.001 ; \beta=0.110$, t-value 2.852, significance $p<0.001$ ) thus, confirming $\mathrm{H} 5, \mathrm{H} 6$ and $\mathrm{H} 7$.

In addition to that technology characteristics had significant influence on performance expectancy, effort expectancy and intention to adopt technology supporting by ( $\beta=0.282$, t-value 5.087 , significance $p<0.001 ; \beta=0.226$, t-value 4.029, significance $p<0.001 ; \beta=0.130$, t-value 3.862 , significance $p<0.001$ ), confirming $\mathrm{H} 8, \mathrm{H} 9, \mathrm{H} 10$. Results also revealed that innovation valance had a significant influence on the intention to adopt technology in the organization and supported by $H 11$ : $(\beta=0.078, t$-value 2.982, significance $p<0.001$ ). Finally, the relationship between intention to adopt technology in organizations and employee job performance was tested. Results showed that intention to adopt technology had a significant influence on employee job performance and supported by $\mathrm{H} 12$ : $(\beta=0.408$, t-value 6.974 , significance $p<$ 0.001). Thus, the results of the structural equation model showed that the extension of a unified theory of acceptance and use of technology with task technology characteristics was appropriate to examine employee intention to adopt technology and employee job performance.

Estimation of effect sizes $\left(\mathrm{f}^{2}\right)$, predictive relevance $\mathrm{Q}^{2}$. The causal relationship between constructs is confirmed with structural model however the effect size of these relationships is yet to be studied. Therefore, the present study estimates effect size analysis using $\left(f^{2}\right)$ analysis. In structural model coefficient of determination $R^{2}$ explained total variance in endogenous variable therefore, effect size analysis shows individual effect size of each exogenous variable on the endogenous variable. Author like Cohen (1988) «p-value can show you whether an effect exists or not therefore it does not illustrate the size of the effect». Thus, it is important to examine the effect size impact of each construct to determine the importance of the variables. As the current study extends the unified theory of acceptance and use of technology with task technology fit theory, it is important to investigate the predictive relevance of the newly developed model. The predictive relevance of the model is assessed with blindfolding procedure $Q^{2}$ in line with earlier studies (Hair, et al., 2016); (Rahi, 2015). In order to achieve adequate predictive relevance of the research model the values of $Q^{2}$ should be greater than 0 indicate appropriate predictive relevance of the model. Table 7 exhibits the results of the effect size $\left(f^{2}\right)$ analysis, predictive relevance $Q^{2}$ and coefficient of determination $R^{2}$

The extended model is confirmed that both theories have a significant impact on employee intention to adopt the technology. As depicted in Table 7 that user intention to adopt technology was jointly predicted by performance expectancy, effort expectancy, social influence, facilitating condition, task characteristics, technology characteristics and innovation valance and explained $R^{2} 77.0 \%$ variance in employee intention to adopt technology, therefore, employee job performance was predicted by intention to adopt technology and supervisor support and explained $R^{2} 20.6 \%$ variance in employee job performance. These findings showed that the extension of the unified theory of acceptance and use of technology was valid and showed a substantial impact on employee intention to adopt the technology.

Concerning with effect size analysis $\left(f^{2}\right)$ results showed that among all other exogenous variables effort expectancy had a substantial effect on employee intention to adopt the technology. Therefore, performance expectancy, social influence, facilitating condition, task characteristics, technology characteristics and innovation valance had shown small effect size. In employee job performance context, intention to adopt technology had shown medium effect size therefore supervisor support had shown small effect size when determining the role of employee job performance. Thus, the newly extended unified 
theory of acceptance and use of technology model had shown influential results to predict employee intention to adopt technology and employee job performance.

Table 7. Effect size analysis $\left(f^{2}\right)$ and predictive relevance $Q^{2}$

\begin{tabular}{|c|c|c|c|c|}
\hline \multicolumn{5}{|c|}{ Intention to Adopt Technology } \\
\hline Constructs & $R^{2}$ & $Q^{2}$ & $\left(f^{2}\right)$ & Decision \\
\hline Intention to Adopt Technology & 0.770 & 0.561 & & \\
\hline Effort Expectancy (EEX) & & & 0.735 & Substantial \\
\hline Facilitating Conditions (FCC) & & & 0.043 & Small \\
\hline Innovation Valance (INV) & & & 0.026 & Small \\
\hline Performance Expectancy (PER) & & & 0.119 & Small \\
\hline Social Influence (SINF) & & & 0.086 & Small \\
\hline Task Characteristics (TAC) & & & 0.040 & Small \\
\hline Technology Characteristics (TCC) & & & 0.061 & Small \\
\hline \multicolumn{5}{|c|}{ Employee Job Performance } \\
\hline Constructs & $R^{2}$ & $Q^{2}$ & $\left(f^{2}\right)$ & Decision \\
\hline Employee Job Performance & 0.206 & 0.141 & & \\
\hline Intention to Adopt Technology (INT) & & & 0.210 & Medium \\
\hline Supervisory Support (SUS) & & & 0.025 & Small \\
\hline
\end{tabular}

Note: $f^{2}: 0.02$, Small; 0.15, Medium; 0.35, Substantial.

Sources: developed by the authors.

Importance of performance matrix analysis (IPMA). The current study had a complex research model as it extends the unified theory of acceptance and use of technology (UTAUT) with task technology fit theory (TTF) and innovation valance. Thus, it is important to examine constructs in terms of performance and importance for managerial implications. Actually, the importance of-performance matrix analysis (IPMA) shows the importance and performance of the latent constructs using scores. IPMA scores are derived from rescaling the latent constructs from 0 to 100 in line with Rahi (2017) and Hair Jr, Hult, Ringle, and Sarstedt (2016). IPMA analysis contains two types of values including total effects or importance scores and performance scores. For IPMA analysis criterion is that the outcome variable should be selected earlier to analysis. Thus, in this study researcher selected employee job performance as an outcome variable for IPMA analysis. The values of importance (total effect) and performance scores (Index Values) of the variables are exhibited in Table 8.

Table 8. IPMA Total effects and performance

\begin{tabular}{|c|c|c|}
\hline Latent Constructs & $\begin{array}{c}\text { Importance } \\
\text { (Total effect of the latent } \\
\text { variable } \\
\text { Employee Job Performance) }\end{array}$ & $\begin{array}{c}\text { Employee Job Performance } \\
\text { (Index values) }\end{array}$ \\
\hline Effort Expectancy (EEX) & 0.201 & 71.316 \\
\hline Facilitating Conditions (FCC) & 0.049 & 70.735 \\
\hline Intention to Adopt Technology (INT) & 0.442 & 67.413 \\
\hline Innovation Valance (INV) & 0.021 & 77.757 \\
\hline Performance Expectancy (PER) & 0.096 & 59.743 \\
\hline Social Influence (SINF) & 0.065 & 63.214 \\
\hline Supervisory Support (SUS) & 0.165 & 60.358 \\
\hline Task Characteristics (TAC) & 0.133 & 61.452 \\
\hline Technology Characteristics (TCC) & 0.128 & 60.103 \\
\hline
\end{tabular}

Sources: developed by the authors. 
Findings of the IPMA analysis indicates that the newly developed extended unified theory of acceptance and use of technology model has adequate importance and performance value to measure employee job performance. Therefore, within an extended unified theory of acceptance and use of technology model, employee intention to adopt technology had the highest importance value to determine employee job performance. Therefore, employee effort expectancy during the use of the online system had shown the second most important construct. Concerning other constructs such as supervisor support, facilitating condition and social influence had lease importance when determining the role of employee job performance. Concerning with task technology fit theory constructs, results showed that both construct technology characteristics and task characteristics had an intermediate level of power to examine employee job performance. It is worth to note that facilitating condition had a high performance therefore for managerial implication it may be not important construct. The results of IPMA analysis are depicted in Figure 2.

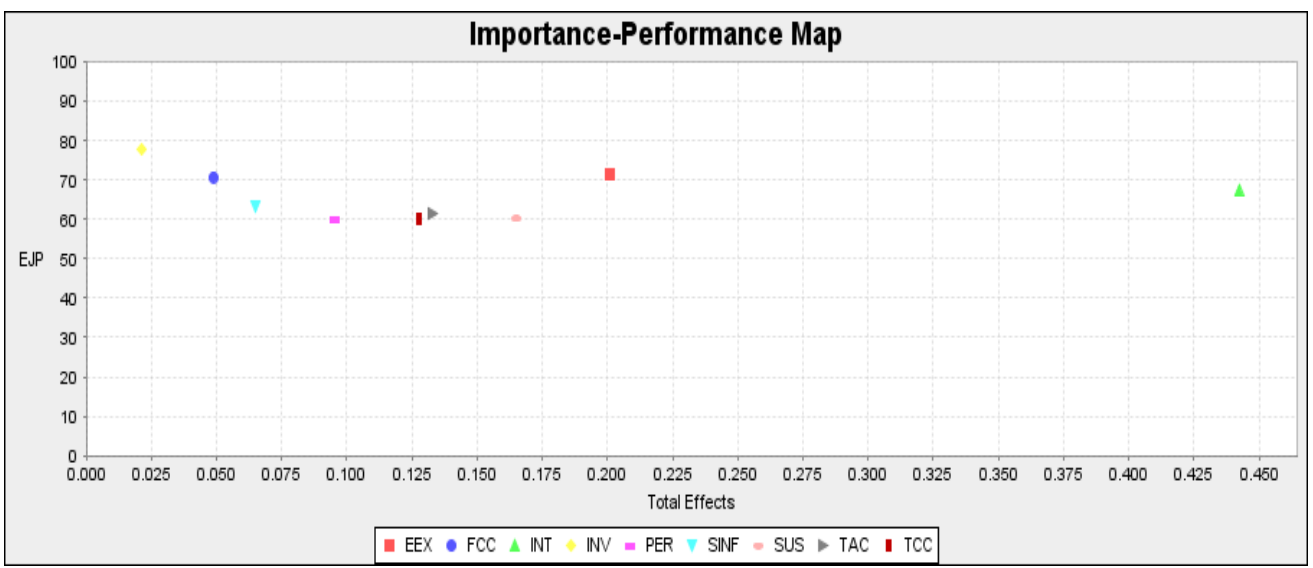

Figure 2. Importance performance matrix analyses map

The importance-performance map as shown in Fig.2 IPMA depicts that for managerial implications, employee intention to adopt technology and employee expectation towards effort (effort expectancy) were the most influential factors when determining the role of employee job performance. Therefore, performance expectancy, task characteristics, technology characteristics and supervisor support had an intermediate level of importance in the extended model. Thus, for managerial implication, it is suggested that manager and policymakers should focus on effort expectancy, task characteristics, technology characteristics and supervisor support to enhance employee intention towards the adoption of technology and employee job performance in public sector organizations.

Moderating analysis. The research model underpinned supervisor support as a moderator variable that moderate the relationship between employee intention to adopt technology and employee job performance in public sector organization. The researcher hypothesized that «the positive relationship between intention to adopt technology and employee job performance will be stronger when supervisor support is higher» For statistical analysis product-indicator approach was used which is in line with (Henseler and Fassott, 2010) and (Samar Rahi, 2016). Product indicator approach is required interaction effect of the independent variable and moderator variable. Thus, the researcher created the interactioneffect of intention to adopt technology and supervisor support to further test a causal linkage between moderator and dependent variable. Findings showed that the interaction effect between intention to adopt internet technology and supervisor support was positive and statistically significant $(\beta=0.297$, t-value 
2.174, $p<0.01$ ), hence confirmed $\mathrm{H} 13$. The result of the moderating effect which includes path coefficient $\beta$ and t-statistic values are exhibited in Figure 3.

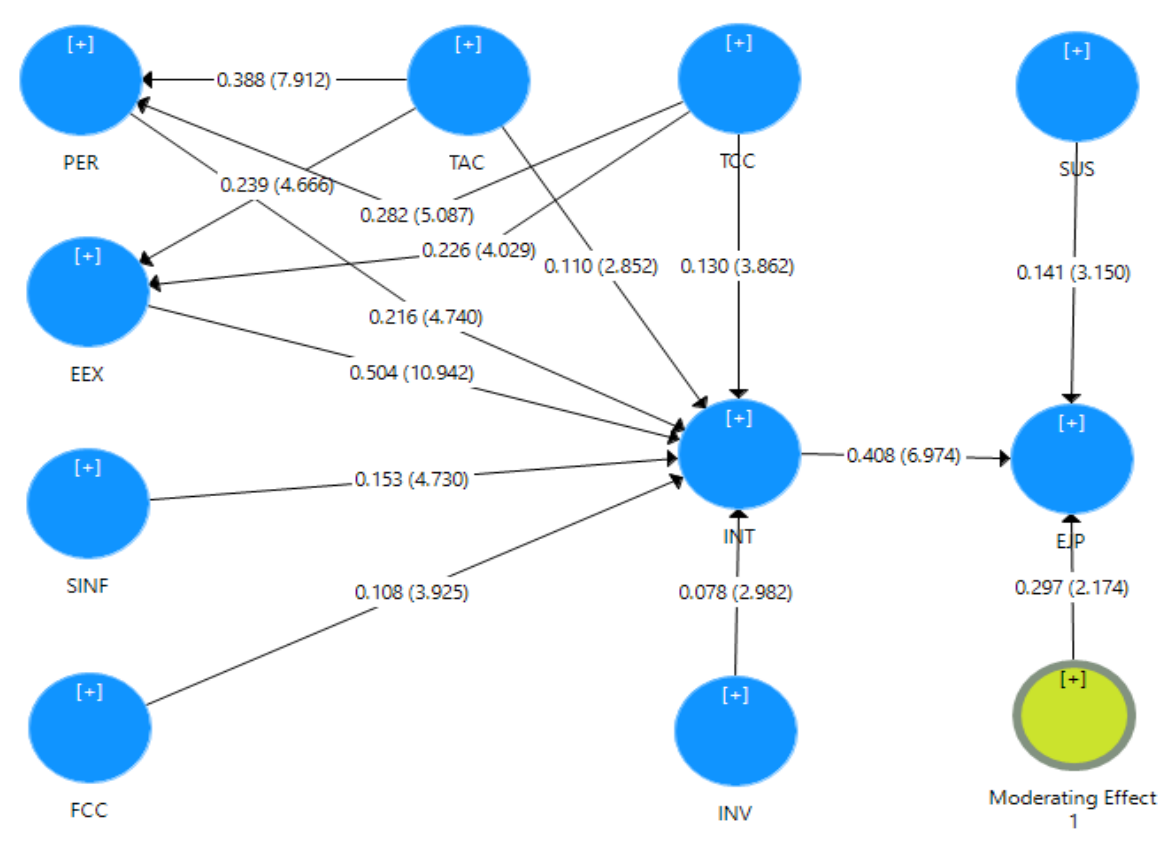

Figure 3. Path coefficients and T-Values

Foremost the moderating relationship of supervisor support between employee intention to adopt technology and employee job performance is statistically confirmed. Therefore, the strength of the moderating relationship whether it is higher or lower yet to be examined. Thus, the researcher took help from simple slope analysis. As stated above this study outlined moderating variable as «the positive relationship between intention to adopt technology and employee job performance will be stronger when supervisor support is higher» is confirmed with simple slope analysis. The simple slope analysis showed a positive trend and described as supervisor support (SUS) at+1SD has steeper and positive gradient when it is compared to supervisor support (SUS) at-1SD (less steep and positive) (Samar Rahi \& Ghani, 2016 , 2018). This trend explained that the positive relationship between intention to adopt technology and employee job performance will be stronger when supervisor support is higher and confirmed $\mathrm{H} 13$. The simple slope analysis is exhibited in Figure 4

This study investigates employee intention to adopt technology in public sector organizations and its impact on employee performance. With the rapid growth of information technology, it is important to investigate how technology impact on employee job performance. Therefore, the present study extends the unified theory of acceptance and use of technology with task technology fit. Findings of the structural equation modelling revealed a significant impact on employee intention to adopt technology and employee job performance. The first construct of UTAUT theory namely performance expectancy significantly influence on intention to adopt technology and in line with (Brown et al., 2010; Ling Keong et al.,2012; Venkatesh and Davis, 2000; Virdyananto et al., 2016; Samar Rahi, 2019; Venkatesh et al., 2003b). Employee effort expectancy had shown significant influence on the intention to adopt technology and in line with (Brown et al., 2010; Venkatesh et al., 2003b). The third and fourth constructs of UTAUT were 
also significant. Results showed that social influence and facilitating condition had positive and significant influence on intention to adopt technology and in line with several previous studies (Brown et al., 2010; Ling Keong et al., 2012; Martins et al., 2014; Rahi, 2019; Venkatesh et al., 2003b; Venkatesh et al., 2012).

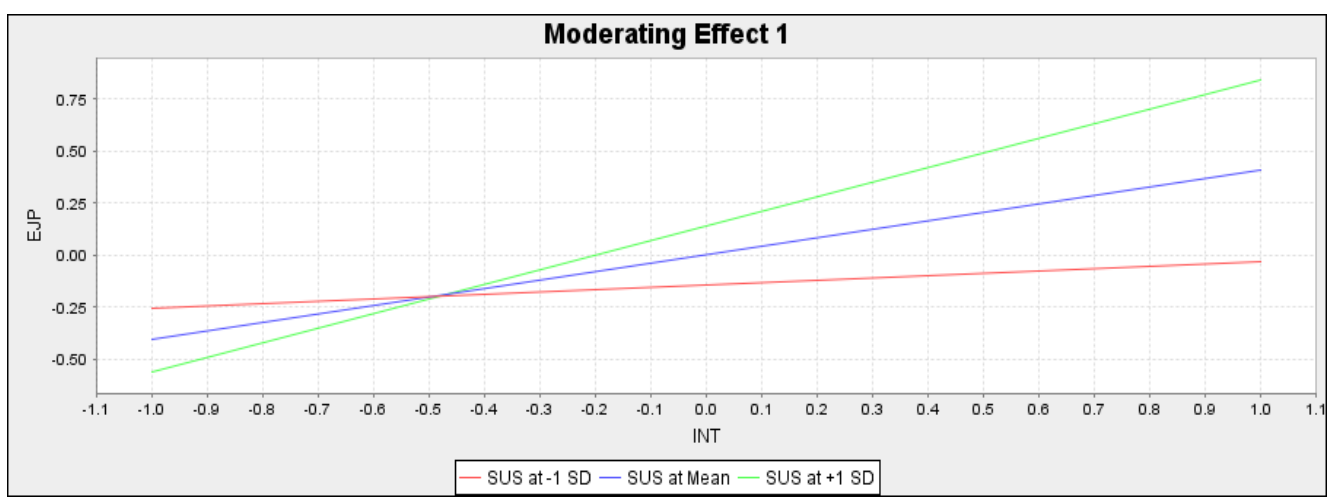

Figure 4. Simple slope analysis for relationship strength

The results of structural equation modelling showed that task characteristics and technology characteristics had a significant relationship with the intention to adopt the technology. Task characteristics significantly influence on performance expectancy, effort expectancy and intention to adopt technology and in line with (Mohammad \& Swaiess, 2019; Oliveira et al., 2014; Tam \& Oliveira, 2016; Zhou et al., 2010). Extending to these technology characteristics had a significant influence on performance expectancy, effort expectancy and intention to adopt technology and in line with previous studies (Oliveira et al., 2014; Tam \& Oliveira, 2016; Zhou et al., 2010). Overall, this study concludes that managers and policymakers should focus on factors underpinned the unified theory of acceptance and use of technology and task technology fit to enhance technology adoption and job performance among public sector employees.

Conclusions. The use of information technology is indispensable for organizational operations. Use of technology not only reduces the operational cost but at the same time it improves employee job performance. In this essence, the current study extends the unified theory of acceptance and use of technology (UTAUT) with task technology fit (TTF) to see how underpinned factors impact on employee intention to adopt information technology and enhance employee job performance. For data analysis, structural equation modelling (SEM) approach is used. Results indicate that the extended UTAUT model has a substantial impact on employee intention to adopt technology and job performance. Employee intention to adopt technology is jointly predicted by performance expectancy, effort expectancy, social influence, facilitating condition, task characteristics, technology characteristics and innovation valance and explained $R^{2} 77.0 \%$ variance in employee intention to adopt technology, therefore, employee job performance was predicted by intention to adopt technology and supervisor support and explained $R^{2}$ $20.6 \%$ variance in employee job performance. These findings showed that the extension of the unified theory of acceptance and use of technology was valid and showed a substantial impact on employee intention to adopt the technology. The effect size analysis $\left(f^{2}\right)$ showed that among all other exogenous variables effort expectancy had a substantial effect on employee intention to adopt the technology. The predictive relevance of the model is assessed with blindfolding procedure $Q^{2}$ which indicates that the values of $Q^{2}$ are be greater than 0 indicate appropriate predictive relevance of the research model. Finally, managerial implications are suggested using importance-performance matrix analysis. Findings of the Importance of performance matrix analysis revealed that employee intention to adopt technology and effort 
expectancy are the most influential factors when determining the role of employee job performance. Thus, for managerial implications, it is recommended that managers and policymakers should focus on effort expectancy, task characteristics, technology characteristics and supervisor support to boost employee intention to adopt technology and employee job performance.

Limitations and future research directions. The present study extends the unified theory of acceptance and use of technology with task technology fit theory (TTF) in order to investigate employee intention to adopt information system in Public sector organization. Although the extension of UTAUT and TTF had shown a substantial impact on employee intention to adopt technology and employee job performance therefore, it has some limitations that are important to acknowledge for future impetus. First, the research model incorporates only government employees in data set adding private sector employee's observation into a data set could reveal interesting findings. Second, the present study is followed by the positivist paradigm and cross-sectional in nature. However, the future researcher may examine this research model in longitudinal and mandatory setting instead of voluntary. Finally, the current research model is tested in Arab countries therefore for research model generalizability the research model could be investigated in other developing regions, for instance, South Asia.

\section{References}

Ahmad, A. R., \& Marinah, A. (2013). Learning organization and organizational commitment in primary school. International Proceedings of Economics Development and Research, 60, 55.

Aizen, I. (1991). The theory of planned behavior. Organizational behavior and human decision processes, 50(2), 179-211.

Al-Alawi, A. I., \& Al-Bassam, S. A. (2019). Evaluation of telecommunications regulatory practice in the Kingdom of Bahrain: development and challenges. International Journal of Business Information Systems, 31(2), 282-303.

Aldholay, A., Isaac, O., Abdullah, Z., Abdulsalam, R., \& Al-Shibami, A. H. (2018). An extension of Delone and McLean IS success model with self-efficacy: Online learning usage in Yemen. The International Journal of Information and Learning Technology, 35(4), 285-304.

Anderson, J. C., \& Gerbing, D. W. (1988). Structural equation modeling in practice: A review and recommended two-step approach. Psychological bulletin, 103(3), 411.

Armenakis, A. A., Bernerth, J. B., Pitts, J. P., \& Walker, H. J. (2007). Organizational change recipients' beliefs scale: Development of an assessment instrument. The Journal of applied behavioral science, 43(4), 481-505.

Bandura, A., Freeman, W., \& Lightsey, R. (1999). Self-efficacy: The exercise of control: Springer.

Bergiel, E. B., Nguyen, V. Q., Clenney, B. F., \& Stephen Taylor, G. (2009). Human resource practices, job embeddedness and intention to quit. Management Research News, 32(3), 205-219.

Brown, S. A., Dennis, A. R., \& Venkatesh, V. (2010). Predicting collaboration technology use: Integrating technology adoption and collaboration research. Journal of management information systems, 27(2), 9-54.

Choi, J. N. (2004). Individual and contextual predictors of creative performance: The mediating role of psychological processes. Creativity Research Journal, 16(2-3), 187-199.

Cohen, J. (1988). Statistical power analysis for the behavioural sciences. Hillside. NJ: Lawrence Earlbaum Associates.

Daud Norzaidi, M., Choy Chong, S., Murali, R., \& Intan Salwani, M. (2007). Intranet usage and managers' performance in the port industry. Industrial Management \& Data Systems, 107(8), 1227-1250.

Davis, F. D., Bagozzi, R. P., \& Warshaw, P. R. (1989). User acceptance of computer technology: a comparison of two theoretical models. Management science, 35(8), 982-1003.

Dewett, T. (2007). Linking intrinsic motivation, risk taking, and employee creativity in an R\&D environment. R\&D Management, 37(3), 197-208.

Fishbein, M., \& Ajzen, I. (1975). Belief. Attitude, Intention and Behavior: An Introduction to Theory and Research Reading, MA: Addison-Wesley, 6.

Fornell, C., \& Larcker, D. F. (1981a). Structural Equation Models With Unobservable Variables and Measurement Error: Algebra and Statistics. Journal of marketing Research, 18(3), 382.

Fornell, C., \& Larcker, D. F. (1981b). Structural equation models with unobservable variables and measurement error: Algebra and statistics. Journal of Marketing Research, 382-388.

Gold, A. H., \& Arvind Malhotra, A. H. S. (2001). Knowledge management: An organizational capabilities perspective. Journal of Management Information Systems, 18(1), 185-214. 
Goodhue, D. L. (1995). Understanding user evaluations of information systems. Management science, 41(12), 1827-1844 Goodhue, D. L., \& Thompson, R. L. (1995). Task-technology fit and individual performance. MIS quarterly, 213-236.

Ha, S. T., \& Lo, M. C. (2018). An empirical examination of knowledge management and organisational performance among Malaysian manufacturing SMEs. International Journal of Business Innovation and Research, 17(1), 23-37.

Hair, J., Anderson, R., Black, B., \& Babin, B. (2016). Multivariate Data Analysis: Pearson Education.

Hair Jr, J. F., Hult, G. T. M., Ringle, C., \& Sarstedt, M. (2016). A primer on partial least squares structural equation modeling (PLS-SEM): Sage Publications.

Hanaysha, J. (2016). Testing the effects of employee engagement, work environment, and organizational learning on organizational commitment. Procedia-Social and Behavioral Sciences, 229, 289-297.

Henseler, J., \& Fassott, G. (2010). Testing moderating effects in PLS path models: An illustration of available procedures Handbook of partial least squares (pp. 713-735): Springer.

Hirst, G., Van Dick, R., \& Van Knippenberg, D. (2009). A social identity perspective on leadership and employee creativity. Journal of Organizational Behavior: The International Journal of Industrial, Occupational and Organizational Psychology and Behavior, 30(7), 963-982.

Hung, C.-Y., Sun, J. C.-Y., \& Yu, P.-T. (2015). The benefits of a challenge: student motivation and flow experience in tabletPC-game-based learning. Interactive Learning Environments, 23(2), 172-190.

loimo, R. E., \& Aronson, J. E. (2003). The benefits of police field mobile computing realized by non-patrol sections of a police department. International Journal of Police Science \& Management, 5(3), 195-206.

Isaac, O., Abdullah, Z., Aldholay, A. H., \& Ameen, A. A. (2019). Antecedents and outcomes of internet usage within organisations in Yemen: An extension of the Unified Theory of Acceptance and Use of Technology (UTAUT) model. Asia Pacific Management Review.

Kline, R. (2011). Principles and Practice of Structural Equation Modeling, 3rd edn Guilford Press. New York.

Ling Keong, M., Ramayah, T., Kurnia, S., \& May Chiun, L. (2012). Explaining intention to use an enterprise resource planning (ERP) system: an extension of the UTAUT model. Business Strategy Series, 13(4), 173-180.

Lockwood, N. R. (2007). Leveraging employee engagement for competitive advantage. Society for Human Resource Management Research Quarterly, 1(1), 1-12.

Lokuge, S., Sedera, D., Grover, V., \& Dongming, X. (2019). Organizational readiness for digital innovation: Development and empirical calibration of a construct. Information \& management, 56(3), 445-461.

Lokuge, S., Sedera, D., \& Nanayakkara, K. S. (2018). Innovate or copy: a Qualitative Document Analysis to Entrepreneurship in Developing Countries. Paper presented at the ECIS.

Makokha, M. W., \& Ochieng, D. O. (2014). Assessing the Success of ICT's from a User Perspective: Case Study of Coffee Research Foundation, Kenya. Journal of Management and Strategy, 5(4), 46.

Marsick, V. J., \& Watkins, K. E. (1999). Facilitating learning organizations: Making learning count: Gower Publishing, Ltd.

Martins, C., Oliveira, T., \& Popovic, A. (2014). Understanding the Internet banking adoption: A unified theory of acceptance and use of technology and perceived risk application. International Journal of Information Management, 34(1), 1-13.

Mohammad Ali, Y. (2018). The mediating role of ethical organizational climate between HRM practices and HR outcomes in Public Sector of Saudi Arabia. International Journal of Business Excellence, O(0). doi: 10.1504/IJBEX.2019.10016985

Mohammad Ali Yousef Yamin, \& Swaiess, M. (2019). Investigating Employee creative performance with integration of

DeLone and McLean Information system success model and Technology acceptance model: The moderating role of Creative self-efficacy. International Journal of Business Excellence, 0(0). doi: 10.1504/JJBEX.2019.10024168

Oliveira, T., Faria, M., Thomas, M. A., \& Popovic, A. (2014). Extending the understanding of mobile banking adoption: When UTAUT meets TTF and ITM. International Journal of Information Management, 34(5), 689-703.

Ozturk, A. B., Bilgihan, A., Salehi-Esfahani, S., \& Hua, N. (2017). Understanding the mobile payment technology acceptance based on valence theory: A case of restaurant transactions. International Journal of Contemporary Hospitality Management, 29(8), 2027-2049.

Podsakoff, P. M., MacKenzie, S. B., Lee, J.-Y., \& Podsakoff, N. P. (2003). Common method biases in behavioral research: a critical review of the literature and recommended remedies. Journal of applied psychology, 88(5), 879.

Rahi, S. (2015). Moderating Role of Brand Image With Relation to Internet Banking and Customer Loyalty: A Case of Branchless Banking. The Journal of Internet Banking and Commerce, 20(3).

Rahi, S. (2016). Impact of Customer Perceived Value and Customers Perception of Public Relation on Customer Loyalty with Moderating Role of Brand Image. The Journal of Internet Banking and Commerce, 21(2).

Rahi, S. (2017). Research design and methods: A systematic review of research paradigms, sampling issues and instruments development. International Journal of Economics \& Management Sciences, 6(2), 1-5.

Rahi, S. (2017). Structural Equation Modeling Using SmartPLS: CreateSpace Independent Publishing Platform.

Rahi, S. (2018). Research Design and Methods: CreateSpace Independent Publishing Platform.

Rahi, S. (2019). Integration of UTAUT model in internet banking adoption context. Journal of Research in Interactive Marketing, 13(3), 411-435. doi: 10.1108/jrim-02-2018-0032. 


\section{B. A. Alyoubi, M. A. Y. Yamin. The Impact of Task Technology Fit on Employee Job Performance}

Rahi, S., \& Abd. Ghani, M. (2018a). Does gamified elements influence on user's intention to adopt and intention to recommend internet banking? International Journal of Information and Learning Technology, $0(0)$, null. doi: doi:10.1108/IILT05-2018-0045

Rahi, S., \& Abd. Ghani, M. (2018b). The role of UTAUT, DOI, perceived technology security and game elements in internet banking adoption. World Journal of Science, Technology and Sustainable Development, 15(4), 338-356. doi: doi:10.1108/WJSTSD-05-2018-0040.

Rahi, S., \& Abd. Ghani, M. (2019a). Does gamified elements influence on user's intention to adopt and intention to recommend internet banking? International Journal of Information and Learning Technology, 36(1), 2-20. doi: doi:10.1108/JILT05-2018-0045.

Rahi, S., \& Abd. Ghani, M. (2019b). Integration of expectation confirmation theory and self-determination theory in internet banking continuance intention. Journal of Science and Technology Policy Management, 0(0), null. doi: doi:10.1108/JSTPM-062018-0057

Rahi, S., \& Abd. Ghani, M. (2019c). Investigating the role of UTAUT and e-service quality in internet banking adoption setting. The TQM Journal, 31(3), 491-506.

Rahi, S., Abd.Ghani, M., \& Hafaz Ngah, A. (2019). Integration of unified theory of acceptance and use of technology in internet banking adoption setting: Evidence from Pakistan. Technology in Society, 58, 101120. doi: https://doi.org/10.1016/j.techsoc.2019.03.003.

Rahi, S., Alnaser, F. M., \& Ghani, M. A. (2019). Designing survey research: recommendation for questionnaire development, calculating sample size and selecting research paradigms. Economic and Social Development: Book of Proceedings, 1157-1169.

Rahi, S., Ghani, M., Alnaser, F., \& Ngah, A. (2018). Investigating the role of unified theory of acceptance and use of technology (UTAUT) in internet banking adoption context. Management Science Letters, 8(3), 173-186.

Rahi, S., Ghani, M., \& Ngah, A. (2018). A structural equation model for evaluating user's intention to adopt internet banking and intention to recommend technology. Accounting, 4(4), 139-152.

Rahi, S., \& Ghani, M. A. (2016). Customer's Perception of Public Relation in E-Commerce and its Impact on E-Loyalty with Brand Image and Switching Cost. Journal of Internet Banking and Commerce, 21(3).

Rahi, S., \& Ghani, M. A. (2018). A Structural Equation Modeling (SEM-AMOS) for Investigating Brand Loyalty and Customer's Intention towards Adoption of Internet Banking Paper presented at the Economic and Social Development (Book of Proceedings), 29th International Scientific Conference on Economic and Social.

Rahi, S., Ghani, M. A. \& Ngah, A. H. (2020). Factors Propelling the Adoption of Internet Banking: The Role of E-Customer Service, Website Design, Brand Image and Customer Satisfaction. International journal of Business Information System $0(0)$. doi: $10.1504 /$ IJBIS.2020.10020858.

Ringle, C. M., Wende, S., \& Becker, J.-M. (2015). SmartPLS 3. Boenningstedt: SmartPLS GmbH

Samar, R., \& Mazuri, A. G. (2019a). Does gamified elements influence on user's intention to adopt internet banking with integration of UTAUT and General Self-Confidence? International Journal of Business Excellence, $0(0)$. doi: 10.1504/IJBEX.2019.10016706.

Samar, R., \& Mazuri, A. G. (2019b). Integration of DeLone \& McLean and Self-Determination Theory in internet banking continuance intention context. International Journal of Accounting and Information Management, 27(3).

Samar, S., Ghani, M., \& Alnaser, F. (2017). Predicting customer's intentions to use internet banking: the role of technology acceptance model (TAM) in e-banking. Management Science Letters, 7(11), 513-524.

Sarker, S., Valacich, J. S., \& Sarker, S. (2005). Technology adoption by groups: A valence perspective. Journal of the Association for Information Systems, 6(2), 3.

Tam, C., \& Oliveira, T. (2016). Understanding the impact of m-banking on individual performance: DeLone \& McLean and TTF perspective. Computers in Human Behavior, 61, 233-244.

Tierney, P., \& Farmer, S. M. (2002). Creative self-efficacy: Its potential antecedents and relationship to creative performance. Academy of management journal, 45(6), 1137-1148.

Venkatesh, V., \& Davis, F. D. (2000). A theoretical extension of the technology acceptance model: Four longitudinal field studies. Management science, 46(2), 186-204.

Venkatesh, V., Morris, M. G., Davis, G. B., \& Davis, F. D. (2003a). User acceptance of information technology: Toward a unified view. MIS quarterly, 425-478.

Venkatesh, V., Morris, M. G., Davis, G. B., \& Davis, F. D. (2003b). User acceptance of information technology: Toward a unified view1. MIS quarterly, 27(3), 425 .

Venkatesh, V., Thong, J. Y., \& Xu, X. (2012). Consumer acceptance and use of information technology: extending the unified theory of acceptance and use of technology.

Virdyananto, A. L., Dewi, M. A. A., Hidayanto, A. N., \& Hanief, S. (2016). User acceptance of human resource information system: An integration model of Unified Theory of Acceptance and Use of Technology (UTAUT), Task Technology Fit (TTF), and Symbolic Adoption. Paper presented at the 2016 International Conference on Information Technology Systems and Innovation (ICITSI). 


\section{B. A. Alyoubi, M. A. Y. Yamin. The Impact of Task Technology Fit on Employee Job Performance}

Wang, S., \& Noe, R. A. (2010). Knowledge sharing: A review and directions for future research. Human resource management review, 20(2), 115-131.

Wang, Y.-S., \& Liao, Y.-W. (2008). Assessing eGovernment systems success: A validation of the DeLone and McLean model of information systems success. Government Information Quarterly, 25(4), 717-733.

Yen, D. C., Wu, C.-S., Cheng, F.-F., \& Huang, Y.-W. (2010). Determinants of users' intention to adopt wireless technology: An empirical study by integrating TTF with TAM. Computers in Human Behavior, 26(5), 906-915.

Yu, C.-S. (2012). Factors affecting individuals to adopt mobile banking: Empirical evidence from the UTAUT model. Journal of Electronic Commerce Research, 13(2), 104.

Zhou, T., Lu, Y., \& Wang, B. (2010). Integrating TTF and UTAUT to explain mobile banking user adoption. Computers in Human Behavior, 26(4), 760-767.

Бадер А. Альобі, Ph.D., доцент, Університет Джидді (Саудівська Аравія);

Мохаммед Алі Юсеф Ямін, Ph.D., Університет Джидді (Саудівська Аравія).

Вплив інноваційних інформаційно-комунікативних технологій на ефективність роботи працівників

У сучасній динамічній глобальній бізнес-економіиі використання інфрормаційних технологій стає важливим компонентом успіху будь-якої компанії. Зважаючи на це, ия стаття узагальнює аргументи та контраргументи в межах наукової дискусії з питання впливу інноваційних інфоормаційно-комунікативних технологій на еффективність роботи працівників. Дане дослідження розширює уніфіковану теорію сприйняттяя та використання технології з постановкою завдання до иієї технології, що дає можливість побачити, як аналізовані фактори впливають на намір працівника прийняти інформаційні технології та підвищити ефективність власної роботи. Для перевірки запропонованої моделі було використане спостереження респондентів. Крім того, було проведене опитування громадських організацій Саудівської Аравії. Анкета була розповююджена серед керівників середньої ланки, які працюють у відділах з управління персоналом громадських організацій Саудівської Аравії. Критерієм включення респондентів було те, що менеджери з персоналу повинні мати знання про інтернет-сервіси, які пропонують відповідні організації працівникам. Для аналізу даних було використано підхід моделювання структурних рівнянь. Результати показують, що розширена модель має значну потужність і пояснює $R^{2} 77,0 \%$ відхилення в намірах працівника прийняти технологію. Аналіз розміру есректу $\left(f^{2}\right)$ показав, що в межах розширеної моделі тривалість зусиль була найважливішим ффактором. Прогнозна відповідність $Q^{2}$ моделі також виявилася адекватною. У рамках дослідження надані рекомендації керівникам та розробникам у сфер технологій зосередити увагу на тривалості зусиль, характеристиках завдань, технологічних характеристиках та підтримці від керівників, що дасть можливість підвищити наміри співробітників до прийняття технології та підвищити ефрективність роботи працівників.

Ключові слова: ефективність роботи, інноваційність, поширення технологій, модеруючий аналіз, моделювання, супервайзер.

Manuscript received: 25.07.2019.

(C) The author(s) 2019. This article is published with open access at Sumy State University. 